\title{
High quality of bacterial dna extraction from Corbicula fluminea (Müller, 1774) tissue in Kelantan
}

\author{
Dee Koh Han a, Suganthi Appalasamy a , Siti Nor Aini Md Nasir a, Faizuan Abdullah b, Maryana \\ Mohamad Nor c, Aweng Eh Rak a, \\ a Department of Natural Resource and Sustainability, Faculty of Earth Science, Universiti Malaysia Kelantan, Jeli Campus, Locked Bag No. 100, \\ 17600 Jeli, Kelantan, Malaysia \\ ${ }^{b}$ Department of Chemistry, Faculty of Science, Universiti Teknologi Malaysia, 81310 UTM Johor Bharu, Johor, Malaysia \\ c Faculty of Agro-Based Industry, Universiti Kelantan Malaysia, Jeli Campus Locked Bag No. 100, 17600 Jeli, Kelantan, Malaysia
}

"Corresponding author: aweng@umk.edu.my

\section{Article history}

Received 11 Mac 2019

Revised 5 May 2019

Accepted 1 January 2020

Published Online 15 April 2020

\begin{abstract}
Corbicula fluminea is a freshwater clam that is served as a popular traditional food in Kelantan, Malaysia. However, there are limited studies that report on high quality bacterial metagenome deoxyribonucleic acid (DNA) from $C$. fluminea. Therefore, this study compares the effectiveness and efficiency of conventional cetyltrimethylammonium bromide (CTAB) protocol, a commercial kit, and modified CTAB protocol for bacterial DNA extraction from the soft tissue surface of raw $C$. fluminea. The instruments used to examine the quality of the extracted bacterial DNA were DeNovix DS-11 spectrophotometer, gel electrophoresis machine, and UV transilluminator. The results showed that the bacterial DNA extracted from modified CTAB protocol had the highest purity and integrity with the $\mathrm{A}_{260} / \mathrm{A}_{280}$ ratio of $1.92 \pm 0.01$ and $\mathrm{A}_{260} / \mathrm{A}_{230}$ ratio of $1.83 \pm 0.06$ as well as the DNA band with minimum smear. This concludes that modified CTAB protocol is the best approach for the bacterial extraction from the $C$. fluminea.
\end{abstract}

Keywords: Corbicula fluminea, high quality DNA, modified CTAB, bacterial metagenome DNA extraction

(C) 2020 Penerbit UTM Press. All rights reserved

\section{INTRODUCTION}

Corbicula fluminea is a freshwater clam that lives in sandy substrate and can be found in rivers in Malaysia. "Etak salai", a popular snack that is commonly consumed in Kelantan, Malaysia is prepared by smoking $C$. fluminea. Sold as street food in Kelantan, this snack has become the source of the income for the local residents [1]. However, health concern is raised among locals as this food is associated with diarrheal cases outbreak which is caused by river pollution [2]. The polluted river is suspected in contributing the pathogenic bacteria and non-pathogenic bacteria that adhered in $C$. fluminea soft tissue. The bacterial community in the $C$. fluminea tissue is yet to be known.

Conventional bacterial culture methods are often used to identify types of bacteria in environmental samples. Unfortunately, the bacteria that can be cultured in the standard media in the laboratory are only a small fraction of the total diversity that exists in nature [3]. Nowadays, culture-independent techniques in assessing microbial diversity have replaced the conventional culture-based approaches since the modern approach is less biased in determining the true diversity and also less labor intensive compared to the conventional culture-based method [4]. Therefore, metagenomics sequencing on 16S rRNA gene is the solution to the unculturable bacteria. By using this advanced technology, researchers can profile the entire microbial community in complex environmental samples easily and quickly without the need for morphological identification [5].

The extraction of high molecular weight bacterial community DNA and efficient metagenomics sequencing are indispensable. Bacterial community DNA extraction is a process by which DNA is obtained from multiple bacterial species within a community during a single extraction. Since not all bacteria cells are lysed in the same way, thus populations that are easily lysed may be overrepresented by biased DNA extraction method [6]. Researchers have found that biasness exists in community analyses based on different DNA extractions, even when extraction kits are used [7, 8]. Proper DNA extraction protocol can retain the integrity of the extracted DNA by lysing the heterogeneous bacterial cells without degrading the DNA quality [9]. Hence, the extraction of bacterial DNA is crucial in order to obtain high yield and high purity bacterial DNA, besides producing less bias $16 \mathrm{~S}$ rRNA sequencing results. The efficient extraction of bacterial DNA can also eliminate PCR inhibitors including salt, ionic detergent, proteinase, polysaccharides, residual ethanol, and phenol that cause the failure of nucleic acid amplification.

In this study, the bacterial genomic DNA was isolated from the soft tissue surface of the raw $C$. fluminea. Previous studies focused on the bacterial contamination from the gut and soft tissue of the clam and oyster $[10,11,12]$. Besides, several studies had been conducted to compare the DNA extraction on the environmental samples [13, 14]. To date, no study has performed bacterial DNA extraction from $C$. fluminea, especially the bacteria from their soft tissue surface of clam. The whole bacteria have been isolated from the soft tissue surface, instead of from the gut because the bacteria in the gut were reported to be bio-processed, especially Escherichia coli [15]. Gomes and his team [15] analyzed the biofiltration ability of $C$. fluminea to remove bacteria in water. They reported $C$. fluminea was effective to remove the bacteria in water and $98 \%$ of the E. coli was found to be bio-processed in $C$. fluminea gut and soft tissue. Besides, in Kelantan, $C$. fluminea has 
the risk of being exposed to unhygienic seller handling, smoking, and selling sites which also affect the bacterial community on the soft tissue surface of the clam. For example, unhygienic handling transferred the bacteria from the sellers to the clams which are frequently reported as the cause of food poisoning in consumers [16].

Hence, this study aimed to compare the DNA extraction performance between modified cetyltrimethylammonium bromide $(\mathrm{CTAB})$ protocol using conventional CTAB protocol and one of the selected commercial kit on soft tissue surface of $C$. fluminea. The quantity and quality of extracted bacterial DNA were evaluated together with the estimation of time consumption and costs per preparation for each method.

\section{EXPERIMENTAL}

\section{Sample collection}

Approximately hundreds of pieces of raw C. fluminea were obtained from the Golok River (6.0182967 N, 101.9712079 E) in Rantau Panjang, Kelantan. The samples were collected and sealed in a zip-lock bag, together with the river water. Then, the samples were preserved in a styrofoam box and sent to the Microbiology and Biochemistry Laboratory, Universiti Malaysia Kelantan Jeli Campus for the bacterial DNA extraction.

\section{DNA extraction}

The shell of the $C$. fluminea was opened using sterilized forceps and scalpel blade (Fig. 1A). Soft tissue of $C$. fluminea was run through with sterilized water and the water was collected using a sterilized glass petri dish $(150 \mathrm{~mm}$ X $20 \mathrm{~mm})$. These steps were repeated for fifteen pieces of $C$. fluminea randomly. The water contained total bacteria that populated on the soft tissues of $C$. fluminea. Then, the water was subjected to three bacterial genomic DNA extraction protocols (Fig. 1B).

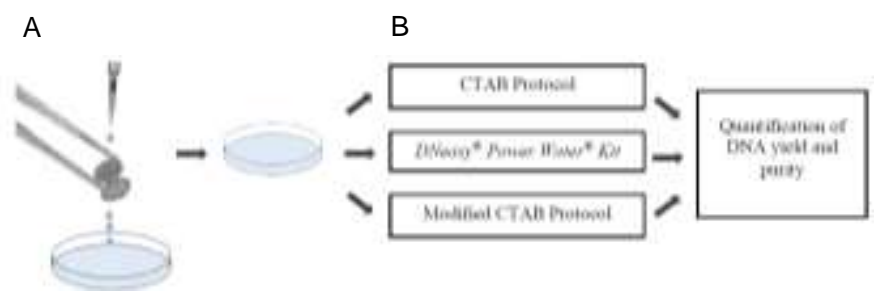

Fig. 1 Overview of experimental design. A schematic diagram that shows how $C$. fluminea were processed for the bacterial genomic DNA extraction.

\section{CTAB protocol}

Bacterial DNA extraction with conventional CTAB protocol was conducted [17]. The water contained bacteria community was pipetted into $2 \mathrm{ml}$ Eppendorf microcentrifuge tubes and centrifuged at 10,000 rpm, for 5 minutes. DNeasy® Power Water ${ }^{\circledR}$ Kit

Bacterial DNA was extracted using the DNeasy ${ }^{\circledR}$ Power Water ${ }^{\circledR}$ Kit (Qiagen, Hilden, Germany), according to the manual provided by the manufacturer. Membrane filters $(0.45 \mu \mathrm{m})$ were used in this step.

\section{Modified CTAB protocol}

Exactly $1.5 \mathrm{~mL}$ of prepared water that contained bacteria community in petri dish was pipetted into $2 \mathrm{ml}$ Eppendorf microcentrifuge tubes. The tube was centrifuged at $10,000 \mathrm{rpm}$ for 5 minutes and the supernatant was discarded. About $700 \mu \mathrm{L}$ Tris- $\mathrm{HCl}-$ EDTA (TE) buffer and $5 \mu \mathrm{L}$ of $100 \mathrm{mg} / \mathrm{ml}$ lysozyme were added into the tube with pellet, mixed well, and incubated at $37^{\circ} \mathrm{C}$ for $15 \mathrm{~min}$. Then, $30 \mu \mathrm{L}$ of $10 \%$ sodium dodecyl sulphate (SDS) and $3 \mu \mathrm{L}$ of 20 $\mathrm{mg} / \mathrm{mL}$ proteinase $\mathrm{K}$ were added. The mixtures were mixed well and incubated at $37{ }^{\circ} \mathrm{C}$ for an hour. After that, $100 \mu \mathrm{L}$ of $5 \mathrm{M} \mathrm{NaCl}$ was added and mixed well. Around $80 \mu \mathrm{L}$ of $\mathrm{CTAB} / \mathrm{NaCl}$ solution was added into the mixtures and mixed well before they are incubated at 65 ${ }^{\circ} \mathrm{C}$ for 10 minutes. Then, an equal volume of $24: 1$ chloroform/isoamyl alcohol (CIA) was added and flipped for 15 minutes. The mixture was centrifuged at 14,500 rpm for 10 minutes. Three layers were formed. The upper layer of the mixture was transferred carefully to a new $2 \mathrm{~mL}$ microcentrifuge tube without touching the middle layer (junk layer). An equal volume of CIA was added again and flipped briefly. The mixture was centrifuged at $14,500 \mathrm{rpm}$ for 10 minutes. Three layers were formed. The upper layer of the mixture was transferred to a new $2 \mathrm{~mL}$ microcentrifuge tube. Exactly 0.6 volume of cold isopropanol was added. The tube rack was shaken until a stringy white DNA precipitate was visible. If the precipitate is not visible, the tubes should be incubated at $-20{ }^{\circ} \mathrm{C}$ in a freezer for 15 minutes. Then, the tube was centrifuged at $14,500 \mathrm{rpm}$ for 15 minutes. The supernatant was discarded and the DNA pellet was washed by adding $1 \mathrm{~mL}$ cold $70 \%$ ethanol. The DNA pellet was dislodged by flipping the tube a few times and kept in ice for at least an hour. The tube was then centrifuged at $14,500 \mathrm{rpm}$ for 5 minutes. Lastly, the pellet was air-dried until completely dried and dissolved in $100 \mu \mathrm{L}$ TE buffer. The DNA pellet was placed in the chiller for a night or two nights until the DNA was completely dissolved. The DNA solution stored in the freezer at $-20^{\circ} \mathrm{C}$ (Fig. 2).

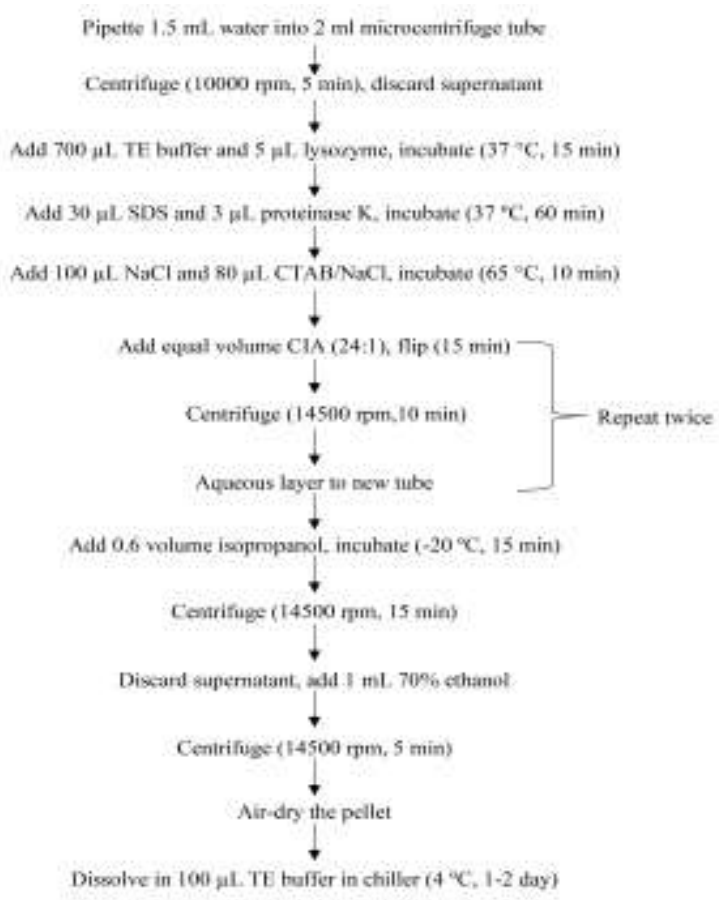

Fig. 2 Schematic diagram for modified CTAB Protocol.

\section{Quantification of DNA yield and purity}

The spectrophotometric purity and yield of extracted bacterial DNA were quantified by the absorbance ratio using DeNovix DS-11 Spectrophotometer [18]. The extracted DNA was quantified at an absorbance of $260 \mathrm{~nm}$ and $280 \mathrm{~nm}$. Besides the 260/280 ratio, 260/230 ratio is widely used as a secondary measure of DNA purity $[19,20]$. The quality and fragmentation of the extracted bacterial DNA were examined using gel electrophoresis in $1 \%(\mathrm{w} / \mathrm{v})$ TAE agarose gel electrophoresis (containing RedSafe ${ }^{\mathrm{TM}}$ Nucleic Acid Staining Solution) and visualized under the UV transilluminator. The results of each extraction method were compared in order to obtain good quality and high yield bacterial DNA from soft tissue surface of $C$. fluminea.

\section{Data analysis}

The quantification of bacterial DNA yield and purity were analyzed in triplicates. The data obtained were presented as mean \pm standard deviation and data analyses were performed using Microsoft Excel 2016.

\section{RESULTS AND DISCUSSION}

In this study, three different extraction methods (CTAB protocol, Qiagen DNeasy ${ }^{\circledR}$ Power Water ${ }^{\circledR}$ Kit, modified CTAB protocol) were applied to the whole bacteria on the raw $C$. fluminea soft tissue surface. 
The bacterial DNA yield, purity, integrity, fragmentation, the duration, and cost of the DNA extraction protocols were analyzed.

\section{DNA yield and purity}

Based on the spectrophotometer results (Table 1), the $\mathrm{A}_{260 / 280}$ ratios for all bacterial genomic DNA are found to be within the range of 1.45 \pm 0.11 to $1.92 \pm 0.01$. For the yield, the highest concentration of DNA was obtained using Qiagen DNeasy ${ }^{\circledR}$ Power Water ${ }^{\circledR}$ Kit, followed by modified CTAB protocol and the conventional CTAB protocol.

Table 1 DNA yield and purity comparison from three bacterial DNA extraction protocols. Bacterial DNA concentration, $A_{260} / A_{280}$ ratio, and $A_{260} / A_{230}$ ratio were calculated using the measurement from DeNovix DS11 Spectrophotometer.

\begin{tabular}{cccc}
\hline $\begin{array}{c}\text { DNA } \\
\text { Extraction } \\
\text { Protocol }\end{array}$ & $\begin{array}{c}\text { Concentration of } \\
\text { dsDNA }(\mathrm{ng} / \mu \mathrm{L})^{\mathrm{a}}\end{array}$ & $\begin{array}{c}\text { Reading of } \\
\mathrm{A}_{260 / 280}\end{array}$ & $\begin{array}{c}\text { Reading of } \\
\mathrm{A}_{260 / 230}\end{array}$ \\
\hline CTAB & $19.75 \pm 10.95$ & $1.45 \pm 0.11$ & $0.50 \pm 0.07$ \\
$\begin{array}{c}\text { DNeasy } \\
\text { Power } \\
\text { Water }\end{array}{ }^{\circledR}$ Kit & $211.38 \pm 1.24$ & $1.78 \pm 0.04$ & $2.06 \pm 0.08$ \\
$\begin{array}{c}\text { Modified } \\
\text { CTAB }\end{array}$ & $155.86 \pm 1.78$ & $1.92 \pm 0.01$ & $1.83 \pm 0.06$ \\
\hline $\mathrm{a}^{*}$ in $100 \mu \mathrm{L}$ & & &
\end{tabular}

The extracted DNA was suitable for PCR reaction when the reading of the ratio of $\mathrm{A}_{260 / 280}$ of DNA range from 1.8 to 2.0 [21]. Based on $\mathrm{A}_{260 / 280}$ reading (Fig. 3.), the highest satisfactory of bacterial DNA result was obtained from the modified CTAB protocol $\left(\mathrm{A}_{260 / 280}=1.92 \pm\right.$ $0.01)$ followed by the yield from Qiagen kit $\left(\mathrm{A}_{260 / 280}=1.78 \pm 0.04\right)$. The DNA extracted from conventional CTAB was in a less satisfactory condition $\left(\mathrm{A}_{260 / 280}=1.45 \pm 0.11\right)$. This is supported by Djurkin Kušec et al. [22] who attained unsatisfactory results at $A_{260 / 280}$ in their DNA extraction using the same conventional CTAB protocol. Meanwhile, Kuhn et al. [23] obtained slightly less satisfactory of A260/280 reading of DNA extraction from activated sludge and river sediment as well as from anaerobic digestion sludge and nitrifying sludge when conventional CTAB protocol was used. The low $\mathrm{A}_{260 / 280}$ ratio indicated the presence of contaminating protein or phenol. This is because residual protein and phenol strongly absorb the UV light from spectrophotometer at $280 \mathrm{~nm}$ that resulted in a low $\mathrm{A}_{260 / 280}$ ratio. It was observed that the conventional CTAB protocol in this study is unable to remove the residual reagent or protein during the DNA extraction.

The $\mathrm{A}_{260 / 230}$ ratio of pure DNA is commonly within the range between 1.8 and $2.2[18,24]$. In this study, $\mathrm{A}_{260 / 230}$ readings showed that highest satisfactory of bacterial DNA were obtained from Qiagen kit $\left(\mathrm{A}_{260 / 230}=2.06 \pm 0.08\right)$ and modified CTAB protocol $\left(\mathrm{A}_{260 / 230}=1.83 \pm\right.$ 0.06), followed by conventional CTAB protocol $\left(\mathrm{A}_{260 / 230}=0.50 \pm 0.07\right)$. The $\mathrm{A}_{260 / 230}$ ratio of bacterial DNA extracted by Qiagen kit and modified CTAB protocol were found within the range of 1.8 to 2.2, while $\mathrm{A}_{260 / 230}$ from conventional $\mathrm{CTAB}$ protocol was less than the ideal range. Low $\mathrm{A}_{260 / 230}$ found in the conventional CTAB protocol shows the presence of contaminants due to absorbance at $230 \mathrm{~nm}$. The contaminant included salt, ethanol, and polysaccharide [25]. This low A 260/230 ratio found in conventional CTAB protocol is supported by Nillian et al. [18] who obtained similar results using phenol-chloroform extraction method on bacterial DNA from saliva samples.

In the case of modified CTAB protocol, the extracted bacterial DNA with high purity shows satisfactory $\mathrm{A}_{260 / 280}$ and $\mathrm{A}_{260 / 230}$ readings. This is because the modified CTAB protocol eliminated phenol to prevent contamination and reduce the hazard all at once since phenol is a carcinogenic substance [26]. Besides, after the addition of chloroform:isoamyl alcohol (24:1), the nucleic acid is well separated from proteins and polysaccharides through centrifugation. In addition, the duration of ethanol washing was increased to at least an hour in the chiller. The prolonged washing period is important to eliminate all the salts in the leftover supernatant and salts that bound to the DNA pellet
[27]. All of these steps result in the elimination of protein and residual reagents.

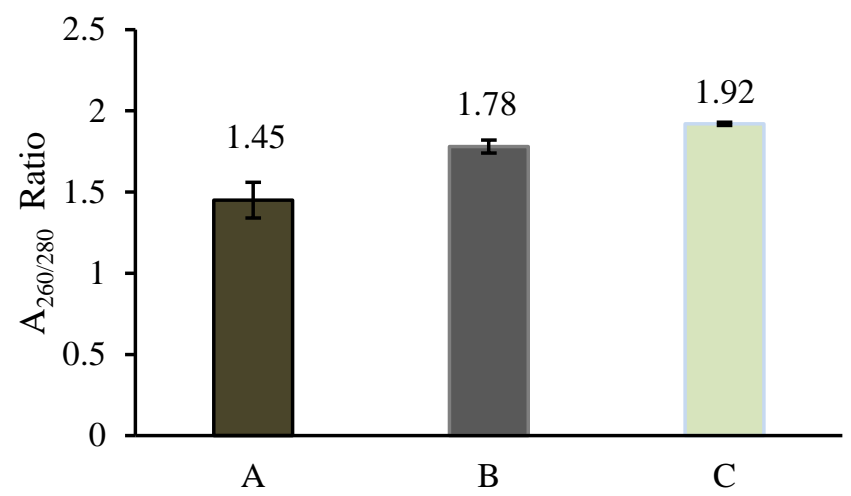

Fig. 3 The bar chart shows the mean value and standard deviation reading of $A_{260 / 280}$ for each extraction protocol using the DeNovix DS-11 Spectrophotometer. A: CTAB protocol (Wilson, 2011); B: Qiagen DNeasy ${ }^{\circledR}$ Power Water ${ }^{\circledR}$ Kit; C: Modified CTAB protocol.

\section{DNA integrity and fragmentation}

The integrity and fragmentation of DNA bands for each extracted bacterial DNA were examined using gel electrophoresis (Fig. 4). Based on the gel electrophoresis results, the DNA bands appear very slightly in bacterial DNA that were extracted using conventional CTAB protocol. Meanwhile, a smear can be observed for the DNA extracted from Qiagen Kit. The DNA band is the clearest without any smear in the DNA extracted from modified CTAB protocol compared to other DNA bands. This showed that the bacterial DNA extracted from modified CTAB protocol is the best among these three methods, producing the highest integrity and purity of bacterial DNA [28]. The storage and handling processes for each sample had been done similarly to minimize the effects on quality of bacterial DNA.

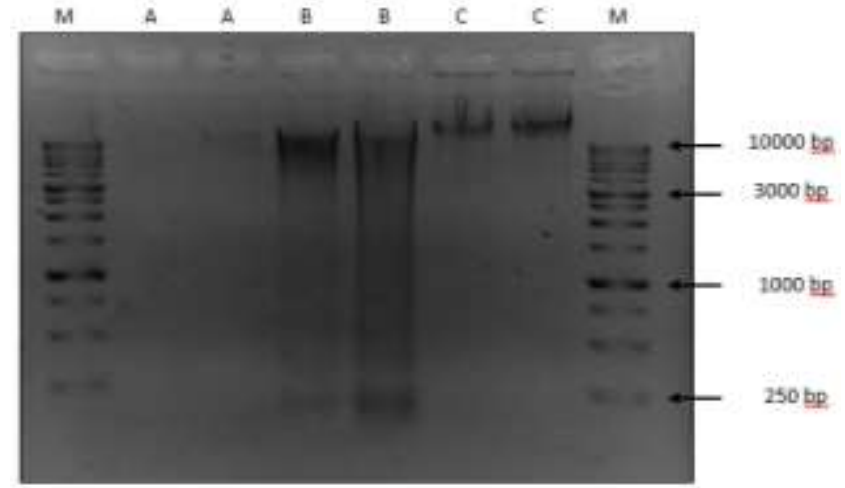

Fig. 4 Agarose gel electrophoresis of extracted bacterial DNA visualized using UV transilluminator. A: CTAB protocol (Wilson, 2011); B: Qiagen DNeasy ${ }^{\circledR}$ Power Water ${ }^{\circledR}$ Kit; C: Modified CTAB protocol. M: 1 kb DNA ladder; Lane 1: $1 \mu \mathrm{L}$ of extracted sample; Lane 2: $3 \mu \mathrm{L}$ of extracted sample; Lane 3: $1 \mu \mathrm{L}$ of extracted sample; Lane 4: $3 \mu \mathrm{L}$ of extracted sample; Lane 5: $1 \mu \mathrm{L}$ of extracted sample; Lane 6: $3 \mu \mathrm{L}$ of extracted sample.

In a previous work, the DNA extracted using the Qiagen kit showed a little smear that indicating a certain level of degradation [29]. This is because the provided elution buffer does not contain EDTA and the DNA was susceptible to degradation with minimum freeze-thaw. When the elution buffer is used to elute DNA, the DNA solution needs to be preserved properly in the freezer $\left(-20{ }^{\circ} \mathrm{C}\right.$ to $\left.-80^{\circ} \mathrm{C}\right)$.

The modified CTAB protocol used lysozyme in the lysis steps to hydrolyze the peptidoglycan in Gram-positive bacteria cell walls in order to reduce biases within the bacterial community [30]. After the DNA pellet has been air-dried, the pellet was dissolved in TE buffer by placing the tube in the chiller overnight with no vortex and heating at all to ensure minimal shear and degradation of the DNA. The EDTA in TE buffer is a powerful metal chelating agent that is capable in protecting DNA from degradation by divalent-metal-dependent 
nucleases [31]. The application of buffer on top of meticulous storage ensure that high quality DNA with minimal degradation can be obtained. Hence, DNA extracted from the modified CTAB protocol produced clear DNA bands without smearing. High quality DNA with minimal degradation reduces amplification failure that affects the metagenomics sequencing on $16 \mathrm{~S}$ rRNA gene.

\section{The duration and cost of the DNA extraction protocols}

The detail of duration and cost range for each extraction protocol per preparation have been calculated (Table 2). Based on Table 2, the extraction kit costed the highest at RM 62.34 per preparation. Meanwhile, the CTAB and modified CTAB cost were almost the same at RM 6.55 and RM 6.25 per preparation, respectively. The high cost of the extraction kit is probably owing to its highly efficient extraction process. Compared to other protocols, the extraction period using the kit was the fastest and can be completed within an hour. The CTAB protocol took 2 hours to complete the extraction, while the modified CTAB took the longest time, about 24 hours to 36 hours. Regardless of its time-consuming process, it is still the cheapest method that produced high quality DNA. Adding a silica bead binding step while using the kit would reduce the time spent, but the cost would be increased.

Table 2 Duration and cost of each extraction method for one preparation. The duration and cost for chemicals, gloves, tubes and tips were calculated based on estimation.

\begin{tabular}{ccccc}
\hline $\begin{array}{c}\text { DNA } \\
\text { Extraction } \\
\text { Method }\end{array}$ & $\begin{array}{c}\text { Time } \\
\text { (hours) }\end{array}$ & $\begin{array}{c}\text { Chemical } \\
\text { (RM/Prep) }\end{array}$ & $\begin{array}{c}\text { Gloves, } \\
\text { tubes, tips } \\
\text { (RM/Prep) }\end{array}$ & $\begin{array}{c}\text { Total Cost } \\
\text { (RM/Prep) }\end{array}$ \\
\hline $\begin{array}{c}\text { CTAB } \\
\text { DNeasy }\end{array}$ & 2 & 2.30 & 4.25 & 6.55 \\
$\begin{array}{c}\text { Power } \\
\text { Water }{ }^{\circledR} \text { Kit }\end{array}$ & 1 & 60.91 & 1.43 & 62.34 \\
$\begin{array}{c}\text { Modified } \\
\text { CTAB }\end{array}$ & $24-36$ & 2.00 & 4.25 & 6.25 \\
\hline
\end{tabular}

As previously mentioned, the whole bacteria community isolation from the soft tissue surface of the $C$. fluminea is essential to prevent the bacteria in the gut from being bio-processed. This can prevent the underestimation of the bacteria composition in $C$. fluminea. The isolation of the bacteria from the soft tissue surface also allow researchers to track the alteration of the bacterial community on the tissue after $C$. fluminea is exposed to different processing sites. This is because the smoking processing site and selling site of $C$. fluminea in Kelantan are suspected to be contaminated with bacteria. With the modified CTAB method, the bacterial metagenome DNA on the soft tissue surface that is extracted in a high quality and integrity condition will allow for the downstream analysis [32]. This modified CTAB method act as the baseline study to help the researchers in acquiring high quality of the bacterial DNA from the soft tissue surface of the $C$. fluminea or other shellfish. It is the cheapest method that enables the researchers in the developing countries to obtain high quality bacteria DNA without using the kit.

\section{CONCLUSION}

The current study has shown that the modified CTAB protocol is better than the conventional CTAB protocol in extracting the bacterial DNA of $C$. fluminea in terms of quality, integrity, and human health risk. In term of extraction duration, the Qiagen DNeasy ${ }^{\circledR}$ Power Water ${ }^{\circledR}$ Kit shows the highest efficiency protocol which requires only one hour, whereas the modified CTAB protocol used up to 24 to 36 hours to complete the extraction process. The drawbacks of the kit can be seen in the cost and potential of DNA degradation. In summary, each studied protocol has its own strengths and weaknesses. The researchers who prefer to use cost-saving protocol without sacrificing the quality and purity of the extraction product are highly recommended to use our modified CTAB protocol to acquire high quality bacterial DNA.

\section{ACKNOWLEDGEMENT}

We are grateful to Universiti Malaysia Kelantan for providing the facility and instrument needed to conduct this study. Besides, this study was fully funded by the Ministry of Higher Education, Malaysia under the Transdisciplinary Research Grant Scheme (TRGS) coded (R/TRGS/A08.00/00244A/005/2016/000389).

\section{REFERENCES}

[1] Aweng, E. R., Kutty, A. A. (2018). Etak, Lokan Air Tawar. Dewan Bahasa dan Pustaka: Dewan Bahasa dan Pustaka.

[2] Aweng, E. R., Mohamed, M. (2011). Water quality and shellfish related gastrointestinal disease cases in Kota Bharu, Kelantan, Malaysia. Journal of Bioentrepreneurship, 1, 9-13.

[3] Stewart, E. J. (2012). Growing unculturable bacteria. Journal of Bacteriology, 194(16), 4151-4160.

[4] Zoetendal, E. G., Collier, C. T., Koike, S., Mackie, R. I., Gaskins, H. R. (2004). Molecular ecological analysis of the gastrointestinal microbiota: A review. The Journal of Nutrition, 134(2), 465-472.

[5] Thomsen, P. F., Willerslev, E. (2015). Environmental DNA - An emerging tool in conservation for monitoring past and present biodiversity. Biological Conservation, 183, 4-18.

[6] Gill, C., van de Wijgert, J. H. H. M., Blow, F., Darby, A. C. (2016). Evaluation of lysis methods for the extraction of bacterial DNA for analysis of the vaginal microbiota. PLoS One, 11(9), e0163148.

[7] Han, Z., Sun, J., Lv, A., Wang, A. (2018). Biases from different DNA extraction methods in intestine microbiome research based on 16S rDNA sequencing: A case in the koi carp, Cyprinus carpio var. Koi. MicrobiologyOpen, e00626.

[8] Vesty, A., Biswas, K., Taylor, M. W., Gear, K., Douglas, R. G. (2017) Evaluating the impact of DNA extraction method on the representation of human oral bacterial and fungal communities. PLoS One, 12(1), e0169877.

[9] Bag, S., Saha, B., Mehta, O., Anbumani, D., Kumar, N., Dayal, M., et al. (2016). An improved method for high quality metagenomics DNA extraction from human and environmental samples. Scientific Reports, 6, 26775.

[10] Aranishi, F., Okimoto, T. (2006). A simple and reliable method for DNA extraction from bivalve mantle. Journal of Applied Genetics, 47(3), 251254.

[11] Hernández-Zárate, G., Olmos-Soto, J. (2006). Identification of bacterial diversity in the oyster Crassostrea gigas by fluorescent in situ hybridization and polymerase chain reaction. Journal of Applied Microbiology, 100(4), 664-672.

[12] Trabal Fernández, N., Mazón-Suástegui, J. M., Vázquez-Juárez, R., Ascencio-Valle, F., and Romero, J. (2014). Changes in the composition and diversity of the bacterial microbiota associated with oysters (Crassostrea corteziensis, Crassostrea gigas and Crassostrea sikamea) during commercial production. FEMS Microbiology Ecology, 88(1), 6983.

[13] Leite, D., Balieiro, F., Pires, C., Madari, B., Rosado, A., Coutinho, H., et al. (2014). Comparison of DNA extraction protocols for microbial communities from soil treated with biochar. Brazilian Journal of Microbiology, 45(1), 175-183.

[14] Psifidi, A., Dovas, C. I., Bramis, G., Lazou, T., Russel, C. L., Arsenos, G., et al. (2015). Comparison of eleven methods for genomic DNA extraction suitable for large-scale whole-genome genotyping and longterm DNA banking using blood samples. PLoS One, 10(1), e0115960.

[15] Gomes, J. F., Lopes, A., Gonçalves, D., Luxo, C., Gmurek, M., Costa, R. et al. (2018). Biofiltration using C. fluminea for E. coli removal from water: Comparison with ozonation and photocatalytic oxidation. Chemosphere.

[16] Puteh, S. E. W., Netty, D., Sangaran, G. (2013). Paper review of factors, surveillance and burden of food borne disease outbreak in Malaysia. Malaysian Journal of Public Health Medicine, 13(2).

[17] Wilson, K. (2001). Preparation of genomic DNA from bacteria. In Current Protocols in Molecular Biology: John Wiley \& Sons, Inc.

[18] Lucena-Aguilar, G., Sánchez-López, A. M., Barberán-Aceituno, C., Carrillo-Avila, J. A., López-Guerrero, J. A., and Aguilar-Quesada, R. (2016). DNA source selection for downstream applications based on DNA quality indicators analysis. Biopreservation and Biobanking, 14(4), 264-270.

[19] Lucena-Aguilar, G., Sánchez-López, A. M., Barberán-Aceituno, C., Carrillo-Avila, J. A., López-Guerrero, J. A., Aguilar-Quesada, R. (2016). DNA source selection for downstream applications based on DNA quality indicators analysis. Biopreservation and Biobanking, 14(4), 264-270. 
[20] Usman, T., Yu, Y., Liu, C., Fan, Z., Wang, Y. (2014). Comparison of methods for high quantity and quality genomic DNA extraction from raw cow milk. Genetics and Molecular Research, 13(2), 3319-3328.

[21] Sambrook, J., Fritsch, E. F., Maniatis, T. (2001). Molecular cloning: A laboratory manual: Cold spring harbor laboratory press.

[22] Djurkin Kušec, I., Radišić, Ž., Komlenić, M., Kušec, G. (2015) Comparison of commercial DNA Kits and traditional DNA extraction procedure in PCR detection of pork in dry/fermented sausages. PoljoPrivreda, 21(1 SUPPLEMENT), 199-202.

[23] Kuhn, R., Böllmann, J., Krahl, K., Bryant, I. M., Martienssen, M. (2017). Comparison of ten different DNA extraction procedures with respect to their suitability for environmental samples. Journal of Microbiological Methods, 143, 78-86.

[24] Nillian, E., Rakwi, N. S. H., Bebey, G. (2018). The effect of mouthwash on the DNA yield and quality of oral bacteria. Malaysian Journal of Microbiology, 14(5), 407-412.

[25] Qamar, W., Khan, M. R., Arafah, A. (2017). Optimization of conditions to extract high quality DNA for PCR analysis from whole blood using SDS-proteinase K method. Saudi Journal of Biological Sciences, 24(7), 1465-1469.

[26] Gami, A. A. (2014). Phenol and its toxicity. Journal of Environmental Microbiology and Toxicology, 2(1).

[27] El-Ashram, S., Al Nasr, I., Suo, X. (2016). Nucleic acid protocols: Extraction and optimization. Biotechnology Reports, 12, 33-39.

[28] Lee, P. Y., Costumbrado, J., Hsu, C.-Y., Kim, Y. H. (2012). Agarose gel electrophoresis for the separation of DNA fragments. Journal of Visualized Experiments(62).

[29] Klingstrom, T., Bongcam-Rudloff, E., Pettersson, O. V. (2018). A comprehensive model of DNA fragmentation for the preservation of high molecular weight DNA. BioRxiv, 254276.

[30] Alimolaei, M., Golchin, M. (2016). An efficient DNA extraction method for Lactobacillus casei, a difficult-to-lyse bacterium. International Journal of Enteric Pathogens 4(1), 1-6.

[31] Barra, G. B., Santa Rita, T. H., de Almeida Vasques, J., Chianca, C. F., Nery, L. F. A., Santana Soares Costa, S. (2015). EDTA-mediated inhibition of DNases protects circulating cell-free DNA from ex vivo degradation in blood samples. Clinical Biochemistry, 48(15), 976-981.

[32] Hallmaier-Wacker, L. K., Lueert, S., Roos, C., Knauf, S. (2018). The impact of storage buffer, DNA extraction method, and polymerase on microbial analysis. Scientific Reports, 8(1), 6292-6292. 